\title{
THE EFFECT OF POLY(VINYL CHLORIDE) MODIFIER AN D FILLER NATURE ON PROPERTIES OF POLYESTER COMPOSITES
}

\author{
Volodymyr Levytskyi ${ }^{1}$, Diana Katruk ${ }^{1, *}$, Andrii Masyuk ${ }^{1}$, Tomasz Bialopiotrowicz ${ }^{2}$, \\ M ykhaylo Bratychak ${ }^{1}$, Nataliia Chopyk ${ }^{1}$
}

https://doi.org/10.23939/chcht12.01.053

\begin{abstract}
The paper determines the influence of polymer modifier (poly(vinyl chloride)) and finely dispersed inorganic filler on the elastic-deformation and thermophysical properties of polyester materials. The research discovers the change of deformation modulus, elasticity modulus, high elasticity modulus, surface hardness, Vicat softening point, and technological shrinkage of modified polyester composites filled with calcium carbonate and aluminum oxide.
\end{abstract}

Keywords: polyester composite, filler, modification, structure, poly (vinyl chloride).

\section{Introduction}

Currently, the polymer composite materials dominate among the modern construction materials $[1,2]$. Particular attention is focused on the composites based on unsaturated polyester resins (UPR), since these materials have a number of operational and technological properties, including increased resistance to aggressive environments, resistance to temperature action, high moisture stability, high adhesion to the surface of various materials and enhanced physical and mechanical properties [3]. Unsaturated polyester resins are technologically compatible with polymers and fillers different by nature, which provides them with a complex of essential properties. Thereby, the composites based on unsaturated polyester resins could have broad application, particularly in construction industry, namely for the manufacturing of sealants, artificial stone, poured floor, products made of polymer concrete, etc. [4].

Among technologically and economically feasible methods of modification of polyester resins are physical methods based on the combination of polyester oligomers

\footnotetext{
${ }^{1}$ Lviv Polytechnic National University

12, S.Bandery St., 79013 Lviv, Ukraine

${ }^{2}$ The John Paul II Catholic University of Lublin

14, Al. Raclawickie, 20950 Lublin, Poland

*samoiliukd@gmail.com

(c) Levytskyi V., Katruk D., Masyuk A., Bialopiotrowicz T., Bratychak M., Chopyk N., 2018
}

with oligomers of a different nature, and macromolecular compounds. Their application provides materials with the necessary complex of technological and operational properties.

Adding inorganic fine fillers, in particular, $\mathrm{CaCO}_{3}$ and $\mathrm{Al}_{2} \mathrm{O}_{3}$ into polyester composition, along with the impact on technological and operational properties of the modified materials, will regulate the process of binder structuring through the formation of interfacial layers with different characteristics and formation of physical and chemical bonds between the filler surface and molecules of the polymer matrix [5]. In this case, directed adjusting of the properties of modified composites can be realized via nature and content of the filler and polymer modifier due to the influence on their morphology caused by interphase and intermolecular interactions involving the system components $[6,7]$.

Moreover, the research of deformation properties of composites is essential for understanding the behavior of a material under the load of different types (static or dynamic, short or long, etc.), its morphological features and determination of the specific areas of applications.

Adding finely dispersed fillers, especially of inorganic nature, reduces shrinkage and improves water resistance and resistance to the action of aggressive environments of polymer composites [8].

The aim of this work is to determine the influence of polymer modifier (poly(vinyl chloride)) and nature of finely dispersed inorganic filler on mechanical, thermophysical and technological properties of polyester composites.

\section{Experimental}

During the investigation, the unsaturated polyester resin (UPR) marked Estromal A023 ("LERG", Poland) was used for obtaining polyester composites.

UPR curing was conducted in the presence of 1.5-2.0 pts.wt initiator Metox-50 (methyl ethyl ketone peroxide solution in dimethyl phthalate) and $0.2-0.4$ pts.wt accelerator of cobalt naphthenate at room temperature. 
Poly(vinyl chloride) (PVC) of brand Lacovyl PB1156 was used as polymer modifier. We also used the calcium carbonate with the density of $2710 \mathrm{~kg} / \mathrm{m}^{3}$ (the highest possible degree of filling of polyester oligomers during conducting of research is 235 pts.wt. per 100 pts.wt. of oligomer) and aluminum oxide with the density of $3700 \mathrm{~kg} / \mathrm{m}^{3}$ (the highest possible degree of filling polyester oligomers during conducting of research is 150 pts.wt per 100 pts.wt of oligomer) as fine dispersed inorganic fillers. Additionally, the composition was filled with diesterphtalate plasticizer of dibutyl phthalate (DBP), which is compatible with poly(vinyl chloride) (interaction parameter $\chi=-223 \mathrm{~J} / \mathrm{mol}$ ). It also functioned both as a solvent and plasticizer for the unsaturated polyester resin and polyvinyl chloride.

The research of elastic-deformation properties, values of hardness and coefficient of structures of modified polyester materials was carried out with the application of Hepler Consistometer at $293 \mathrm{~K}$. The method is based on indentation of conical indenter under the load of $120 \mathrm{~N}$ and determination of characteristics by the modulus and deformation calculation according to the methodology [9].

Vicat softening point of the investigated materials was determined in accordance with ISO 306:2013, the loading was $50 \mathrm{~N}$.

The surface hardness of conical fluidity point was determined on Hepler Consistometer at $293 \mathrm{~K}$ by indentation of steel cone in the polymer sample with the sharpening angle of $58^{\circ} 08^{\prime}$ under the load of $50 \mathrm{~N}$ for $60 \mathrm{~s}$. Brinnel hardness of the samples was determined according to ISO 2039-1 via diameter of steel balls after removing the load.

Shrinkage of polyester material was measured according to ISO 2577:2007, comparing the size of the obtained sample with the size of a form.

\section{Results and Discussion}

Along with the strength characteristics, such characteristics as elasticity, high elasticity, and plasticity are of great importance for polymer composite materials used for construction purposes. In this work, the above mentioned properties were evaluated according to modulus-deformation method [8]. This method allows estimating material by physical, rheological, and some technological properties. At the same time, research of elastic deformation properties of composites allows us to evaluate comprehensively not only the physical and mechanical properties of the material, but also its uniformity and change of properties depending on the conditions of processing and operation.

Table 1 shows the composition of polyester composites based on unsaturated polyester resins Estromal A023, PVC modifier, and finely dispersed $\mathrm{CaCO}_{3}$ filler.

Table 2 illustrates the research results of elasticdeformation properties of modified polyester materials based on Estromal A023 filled with $\mathrm{CaCO}_{3}$.

As we can see, unfilled UPR (composition 1) is characterized by high values of deformational modulus $\left(E_{d}\right)$ and modulus of elasticity $\left(E_{e}\right)$. Apparently, it is caused by structural features of cross-linked polymers, such as presence of chemical knots of the grid which are practically not destroyed under static loads. Due to the chemical knots of the grid, movement of sufficiently large segments of polyester macromolecules is virtually impossible. Relaxation phenomena related to slow restructuring of chemical bonds of the grid after static load removing can be possible. Herewith, high density of grid reduces the segmental mobility, as evidenced by the high values of high elasticity modulus $\left(E_{h e}\right)$.

Table 1

Polyester material composition

\begin{tabular}{|l|c|c|c|c|c|c|}
\hline \multirow{2}{*}{ Components } & \multicolumn{5}{c|}{ Composition content, pts.wt } \\
\cline { 2 - 7 } & 1 & 2 & 3 & 4 & 5 & 6 \\
\hline Unsaturated polyester resins & 100 & 100 & 100 & 100 & 100 & 100 \\
\hline Poly(vinyl chloride) & - & 20 & - & 20 & - & 20 \\
\hline Dibutyl phthalate & - & - & - & - & 3 & 3 \\
\hline Calcium carbonate & - & - & 235 & 235 & 235 & 235 \\
\hline
\end{tabular}

Table 2

Elastic deformational properties of polyester composites filled with $\mathrm{CaCO}_{3}$

\begin{tabular}{|l|c|c|c|c|c|c|}
\hline \multicolumn{2}{|c|}{ Characteristics } & \multicolumn{5}{c|}{ Values for the compositions } \\
\cline { 2 - 7 } & 1 & 2 & 3 & 4 & 5 & 6 \\
\hline Deformation module $E_{d}, \mathrm{GPa}$ & 2.48 & 2.32 & 4.59 & 4.43 & 4.86 & 4.47 \\
\hline Equilibrium elastic modulus $E_{e}, \mathrm{GPa}$ & 4.29 & 4.44 & 12.24 & 12.15 & 12.64 & 14.43 \\
\hline $\begin{array}{l}\text { Conventionally instantaneous elastic } \\
\text { modulus } E_{\mathrm{o}}, \mathrm{GPa}\end{array}$ & 4.84 & 5.03 & 13.59 & 14.10 & 14.14 & 15.46 \\
\hline High elasticity modulus $E_{h e}, \mathrm{GPa}$ & 38.10 & 37.66 & 123.44 & 88.08 & 119.16 & 215.82 \\
\hline
\end{tabular}


Adding finely dispersed $\mathrm{CaCO}_{3}$ filler in UPR increases the value of deformation modulus of composite that decreases its ability to deformation under static loads. The value of the equilibrium modulus, characterized by interatomic distances change in the chains of macromolecules, as well as bond angles deformation, significantly increases during the process of $\mathrm{CaCO}_{3}$ adding. It is obviously caused by the decrease of mobility of structured polyester resin segments due to interphase interactions with the surface of finely dispersed filler. Along with this, there is a substantial increase of high elasticity modulus for polyester composites. It is characterized by the change of macromolecules conformation and spatial grid restructuring that leads to the decreasing of the material elasticity. Greater values of conventionally instantaneous modulus compared to the equilibrium modulus of elasticity are explained by the fact that the duration of the applied load affects the restructuring of polyester matrix and modifier through the formation of a new focused structure. The possibility of preserving this structure after removing stress is determined by intermolecular interactions between polymer matrix and components of the reaction environment.

At the same time, the increase of elastic modulus and high elasticity of high filled composites is caused by the fact that part of external load is accepted by hard filler particles. It is also caused by the increasing of transition polymer matrix-filler layer thickness, in which macromolecules are characterized by shorter statistical polymer chain segments.

Adding PVC modifier to the polymer composition leads to increasing of elasticity and plasticity of the composite material. It is evident by the increasing elastic modulus and decreasing value of high elasticity modulus as in the case of unfilled and filled materials (compositions 2,4). These features are primarily caused by the formation of partly interpenetrated grid between structured unsaturated polyester resin and PVC macromolecules. Formation of such structure is also due to partial dissolution of PVC in styrene during polyester resin structuring.

Addition of dibutyl phthalate plasticizer to the filled composition results in increased strength characteristics of the material (deformation modulus and elastic modulus increase). These special features are caused by decrease defects of polyester grid owing to the interaction of plasticizer molecules with solid filler surface and change of interphase characteristics of the system polyester matrix-filler.

For filled compositions, the greatest value of elasticity module is observed in the process of adding poly(vinyl chloride) and dibutyl phthalate. These characteristics of the material are obviously related to greater thermodynamic compatibility of PVC with plasticizer than with styrene and, consequently, to the increase of its solubility in the system. At the same time, the composite elasticity decrease is caused by reduction of dibutyl phthalate plasticizing action in relation to polyester component because of its dominant interaction with PVC macromolecules.

It was determined that the nature of finely dispersed filler affects deformation characteristics of modified polyester composites. In the case of applying $\mathrm{Al}_{2} \mathrm{O}_{3}$ as a filler of unmodified polyester compositions, we could observe the similar to $\mathrm{CaCO}_{3}$ effect on deformation modulus and high elasticity modulus (these values increase) (Fig. 1).

However, the deformation modulus decreases in the materials which apart from the filler contain 20 weight part of PVC. This shows that the modified composite is less rigid and hard compared to the unmodified one. Obviously, this is a result of the mobility reduction of atomic groups and segments due to the change in the nature of intermolecular and interphase interactions between PVC modifier and polyester matrix [10]. The study points out [11] the mechanism of the reinforcing impact of thermoplastic modifier on polyester materials that prevents the growth of a large crack during destruction. In addition, microcracks appear in the matrix and destruction takes place by the mechanism of forced high elasticity deformation.

At the same time, adding plasticizer reduces value of deformation modulus and modulus of high elasticity. Obviously, due to the interaction between plasticizer and polymer matrix macromolecule segment their mobility increases. It leads to the reduction of interactions between them and, accordingly, to some worsening of strength properties. During the addition of the plasticizer to the composition containing the filler and polymer modifier, a decrease of elasticity module and deformation is observed. Obviously, it occurs due to the prevailing interaction of plasticizer with PVC and the increase of heterophasing system. The increase of elastic modulus value related to conformational changes of macromolecules for modified polyester materials is also a consequence of changes in the morphology of materials under the influence of interactions between system components. These features indicate a strengthening effect of finely dispersed inorganic fillers. It leads to the limited mobility of macromolecules of polyester and formation in force field around the particles of fine adsorbed layers of ordered supramolecular structures. Such filler effect involves a reduction of the number of possible conformations of macromolecules in these layers. It also involves the increase of medium relaxation time, expansion of relaxation spectrums and density of macromolecules packaging.

Structure coefficient of the grid materials is a characteristic of three-dimensional spatial grid as 
chemical and physical derivation, and to a certain extent describes the intermolecular and interphase interactions between the components.
Influence of the filler nature and polymer modifier on structure coefficient $K$ of the polyester materials is shown in Fig. 2.

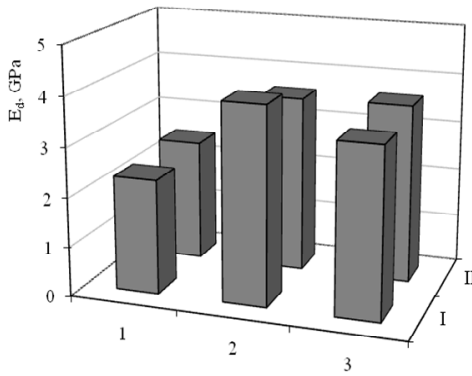

a)

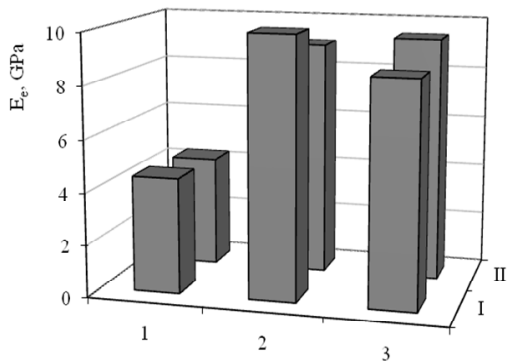

b)

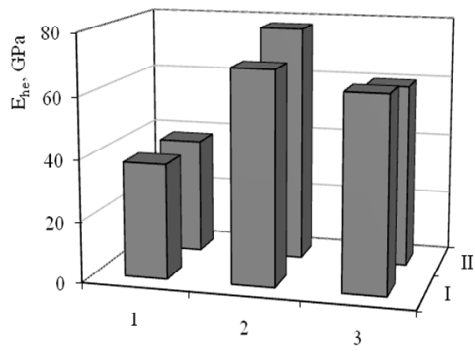

c)

Fig. 1. Effect of aluminum oxide and PVC on elastic-deformation properties of polyester composites: deformation modulus $E_{d}(\mathrm{a})$; equilibrium elastic modulus $E_{e}(\mathrm{~b})$ and high elasticity modulus $E_{h e}(\mathrm{c})$. PVC content, pts.wt: 20 (I) and 0 (II). UPR: $\mathrm{Al}_{2} \mathrm{O}_{3}$ :DBP, pts.wt: 100:0:0 (1); 100:150:0 (2) and 100:150:3 (3)

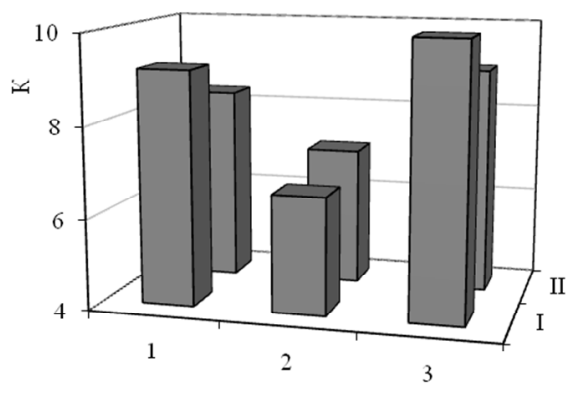

a)

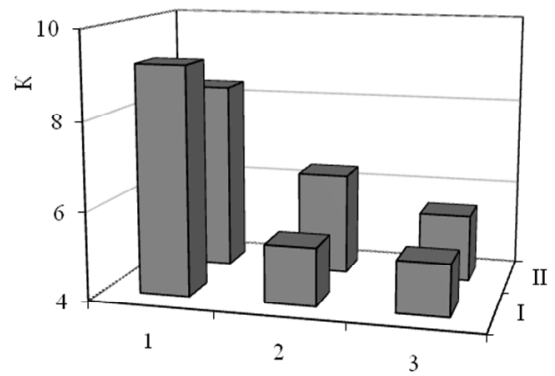

b)

Fig. 2. Influence of filler nature and PVC polymer modifier on structure coefficient $\mathrm{K}$ of polyester composites.

For (a) UPR: $\mathrm{CaCO}_{3}$ :DBP, pts.wt: 100:0:0 (1); 100:235:0 (2) and 100:235:3 (3). PVC content, pts.wt: 20 (I) and 0 (II).

For (b) UPR: $\mathrm{Al}_{2} \mathrm{O}_{3}:$ DBP pts.wt: 100:0:0 (1); 100:150:0 (2) and 100:150:3 (3). PVC content, pts.wt: 20 (I) and 0 (II)

Table 3

The impact of modifier content and nature of finely dispersed inorganic filler on thermal and physico-mechanical properties of polyester materials

\begin{tabular}{|c|c|c|c|c|c|c|}
\hline \multicolumn{2}{|c|}{$\begin{array}{l}\text { Composition content } \\
100 \text { pts.wt of resin }\end{array}$} & \multirow{2}{*}{ Shrinkage, $\%$} & \multirow{2}{*}{$\begin{array}{l}\text { Vicat softening } \\
\text { point, } K\end{array}$} & \multirow{2}{*}{$\begin{array}{c}\text { Surface } \\
\text { hardness, } \mathrm{MPa}\end{array}$} & \multirow{2}{*}{$\begin{array}{l}\text { Hardness, } \\
\qquad \mathrm{MPa}\end{array}$} & \multirow{2}{*}{$\begin{array}{c}\text { Brinnel hardness, } \\
\text { HB }\end{array}$} \\
\hline Filler, pts.wt & PVC, pts.wt & & & & & \\
\hline \multirow{2}{*}{-} & - & 8.6 & $>471 * *$ & 582.3 & 196.9 & 30 \\
\hline & 20 & 7.8 & 399 & 522.2 & 188.4 & 26 \\
\hline \multirow{3}{*}{$\begin{array}{c}\mathrm{CaCO}_{3} \\
235\end{array}$} & - & 7.1 & $>492 * *$ & 643.0 & 296.9 & 48 \\
\hline & 20 & 5.7 & 439 & 599.3 & 289.7 & 34 \\
\hline & 20 & 6.9 & 432 & 589.5 & 291.5 & 36 \\
\hline \multirow{3}{*}{$\begin{array}{c}\mathrm{Al}_{2} \mathrm{O}_{3} \\
150\end{array}$} & - & 7.5 & 453 & 638.9 & 270.3 & 44 \\
\hline & 20 & 5.8 & 416 & 579.4 & 252.1 & 33 \\
\hline & 20 & 7.2 & 403 & 594.6 & 244.4 & 33 \\
\hline
\end{tabular}

Notes: * in the presence of 3 pts.wt of DBP; ** the destruction of the sample. 
As we can see, adding poly(vinyl chloride) to unfilled composition increases the coefficient of the composite structure, which apparently is a consequence of the formation of partly interpenetrated grid of structured polyester resin and PVC macromolecules [12]. It is found out that the addition of inorganic filler, irrespective of its nature, reduces the composite structure coefficient due to the influence of surface filler on the process of oligomers structuring in the studied systems. This may form a threedimensional grid with less density of knots.

Adding poly(vinyl chloride) and inorganic finely dispersed fillers to the polyester compositions allows predetermining the process of structuring polyester binder through the formation of boundary layer on the border of filler-polymer matrix [13]. Therefore, it affects the thermal and physico-mechanical properties of the obtained composite. The impact of the polymer modifier and nature of finely dispersed inorganic filler on thermal and physico-mechanical properties of polyester materials is presented in Table 3 .

It is determined that the modified polyester materials containing finely dispersed inorganic fillers are characterized by various principles of change of the values of surface hardness, Brinnel hardness and Vicat softening point compared to the unfilled materials. Adding finely dispersed inorganic fillers, for instance $\mathrm{CaCO}_{3}$ and $\mathrm{Al}_{2} \mathrm{O}_{3}$ in polyester matrix allows adjusting strength properties of the material. It is found out that adding finely dispersed inorganic fillers leads to higher values of surface hardness and Brinnel hardness. The composites containing PVC polymer modifier represent slightly lower values of hardness, determined in accordance with moduledeformational method of calculation of surface hardness and Brinnel hardness. This apparently is the result of changes in the surface characteristics of the composite, and adding plasticizer increases them as a result of its interaction with PVC. Furthermore, hardness values, determined by various methods, are correlated. These features of polyester material could be explained by the different nature of interactions between polyester resin and filler. It leads to significant changes in the structure of supramolecular polyester matrix and to the change of properties of polyester composite.

Technological shrinkage of polyester material depends on the nature of the filler, modifier content, and on the ratio of the reagents in the composition. It is found out that adding finely dispersed inorganic filler and poly(vinyl chloride) polymer modifier in the polyester matrix causes the reduction of technology shrinkage of the material by $30-35 \%$.

\section{Conclusions}

The study discovers that the nature and content of finely dispersed inorganic filler calcium carbonate and aluminum oxide substantially affect the elastic deformation, thermal and technological properties of modified poly(vinyl chloride) polyester materials.

Highly filled modified polyester composites are characterized by the increased values of Vicat softening point, hardness, modulus of elasticity and reduced values of technological shrinkage. Adding poly(vinyl chloride) leads to increases of highly elastic features of polyester composites. Evidently, it is due to the formation of partly interpenetrated grid involving structured polyesters and poly(vinyl chloride) macromolecules.

Since the developed modified composites are characterized by the increased operational features they could be effectively applied as a basis for artificial stone, poured floor, etc.

\section{References}

[1] Mazumdar S.: Composites Manufacturing: Materials, Product, and Process Engineering. CRC Press, Boca Raton 2002.

[2] Long A. (Ed.): Composites Forming Technologies. Woodhead Publishing Ltd, Cambridge 2007.

[3] Poth U., Polyester und Alkydharze. Vincents Network, Hannover 2014.

[4] Samoliuk D., Levytskyi V.: Khim. Prom. Ukrainy, 2015, 129, 36.

[5] Kozlov G., Afashagova Z., Yanovskiy Yu., Karnet Yu.:

Mehanika Kompoz. Mater. i Konstruktsiy, 2009, 15, 137.

[6] Levytskyi V., Masyuk A., Samoliuk D. et al.: Mat. Sci., 2016, 1,

17. https://doi.org/10.1007/s11003-016-9921-5

[7] Suberlyak O., Levitskij V., Skorokhoda V., Godij A.: Ukr. Khim. Zh., 1998, 5-6, 122.

[8] Xanthos M., Functional Fillers for Plastics. Wiley-VCH Verlag GmbH \& Co. KGaA 2005.

https://doi.org/10.1002/3527605096

[9] Liyv E.: Metodika Opredeleniya Phyziko-Mekhanicheskikh

Svoistv Polymernykh Kompozitov putem Vnedreniya

Konusoobraznogo Indentora. EstNIINTI, Talin 1983.

[10] Levytskyi V., Katruk D., Shybanova A. et al.: Phys.-Khim.

Mekhanika Mater., 2016, 4, 100.

[11] Paul D., Newman S. (Eds.): Polymer Blends, vol. 1.

Academic Press, Oxford 2012.

[12] Lipatov Yu., Sergeeva L.: Vzaymopronykaiushchye Polymernye Setki. Naukova dumka, Kyiv 1979.

[13] Levytskyi V., Masyuk A., Katruk D., Bratychak M.: Chem. Chem. Technol., 2016, 10, 35. https://doi.org/10.23939/chcht10.01.035

Received: April 11, 2017 / Revised: April 24, 2017 / Accepted: July 03, 2017

\section{ВПЛИВ ПОЛІВІНІЛХЛОРИДУ ТА ПРИРОДИ НАПОВНЮВАЧА НА ВЛАСТИВОСТІ ПОЛІЕСТЕРНИХ КОМПОЗИТІВ}

Анотація. Встановлено вплив полімерного модифікатора (полівінілхлориду) та дрібнодисперсного неорганічного наповнювача на пружно-деформачійні та теплофізичні властивості поліестерних матеріалів. Виявлено зміну модуля деформачї, модуля пружності, модуля високоеластичності, поверхневої твердості, теплостійкості за Віка і технологічної усадки модифікованих поліестерних композитів, наповнених кальиію карбонатом і алюмінію оксидом.

Ключові слова: поліестерний композит, наповнювач, модифікування, структура, полівінілхлорид. 